\title{
STRATEGIES DEVELOPED BY COMMUNITY-DWELLING ELDERLY PEOPLE TO LIVE ALONE ${ }^{1}$
}

\author{
Francine Melo da Costa ${ }^{2}$, Priscila Tadei Nakata ${ }^{3}$,Eliane Pinheiro de Morais ${ }^{4}$
}

\footnotetext{
${ }^{1}$ Extract from the thesis - Strategies developed by the elderly to dwell alone, presented to the Programa de Pós-Graduação em Enfermagem (PPGENF) of the Universidade Federal do Rio Grande do Sul (UFRGS), in 2013.

${ }^{2}$ M.Sc. in Nursing. Nurse at the Hospital de Clínicas de Porto Alegre. Porto Alegre, Rio Grande do Sul, Brazil. E-mail: mcfrancine@ gmail.com

${ }^{3}$ Nurse of the Unidade de Saúde da Família Campo Novo. Porto Alegre, Rio Grande do Sul, Brazil. E-mail: priscilanakata@gmail. com

${ }^{4}$ Ph.D. in Fundamentals of Nursing. Adjunct Professor of the Departamento de Assistência e Orientação Profissional da Escola de Enfermagem and the PPGENF/UFRGS. Porto Alegre, Rio Grande do Sul, Brazil. E-Mail: epmorais@hotmail.com
}

\begin{abstract}
The aim of this study was to analyze strategies developed by the elderly in order to live alone. A qualitative, exploratory research was conducted with 14 elderly individuals, who lived in a community that belongs to the area assisted by a basic health unit in a city in southern Brazil. Data were collected through interviews and analyzed by means of the thematic content analysis technique. In order to analyze the strategies, three categories were constructed, according to the identified behaviors. Strategy 1: behaviors in search of social support; strategy 2: behaviors in search of keeping active; strategy 3: behaviors in search of religiosity. The analysis of the strategies developed by the elderly enabled us to understand how they use the available resources to handle difficulties that are inherent to the process of aging.
\end{abstract}

DESCRIPTORS: Aged. Behavior. Housing.

\section{ESTRATÉGIAS DESENVOLVIDAS PELOS IDOSOS RESIDENTES NA COMUNIDADE PARA MORAREM SOZINHOS}

RESUMO: Este estudo objetivou analisar as estratégias desenvolvidas pelos idosos para morarem sozinhos. Trata-se de pesquisa qualitativa do tipo exploratória. Participaram 14 idosos residentes na comunidade pertencente à área de abrangência de uma unidade básica de saúde de um município do Sul do País. As informações foram coletadas por meio de entrevistas e analisadas pela técnica de análise de conteúdo temática. Para a análise das estratégias, foram constituídas três categorias, de acordo com os comportamentos identificados. Estratégia 1: comportamentos em busca de apoio social; estratégia 2: comportamentos em busca de manter-se ativo estratégia 3: comportamentos em busca de religiosidade. A análise das estratégias desenvolvidas pelos idosos possibilitou compreender de que forma utilizam os recursos disponíveis para lidar com as dificuldades inerentes ao processo de envelhecimento.

DESCRITORES: Idoso. Comportamento. Habitação.

\section{ESTRATÉGIAS DESARROLLADAS POR LOS ANCIANOS RESIDENTES EN LA COMUNIDAD PARA VIVIER SOLOS}

RESUMEN: Este estudio objetivó hacer un análisis de las estrategias desarrolladas por los ancianos para que vivan solos. Se trata de una investigación cualitativa de tipo exploratoria. Participaron 14 ancianos residentes en la comunidad perteneciente al área de alcance de una unidad básica de salud de un municipio del sur del País. Las informaciones fueron recolectadas a través de entrevistas y analizadas por medio del contenido temático. Para el análisis de las estrategias se constituyeron tres categorías de acuerdo con los comportamientos identificados. Estrategia 1: comportamientos en búsqueda de apoyo social; estrategia 2: comportamientos en búsqueda de mantenerse activo; estrategia 3: comportamientos en búsqueda de religiosidad. El análisis de las estrategias desarrolladas por los ancianos posibilita comprender la forma en que utilizan los recursos disponibles para lidiar con las dificultades inherentes al proceso de envejecimiento. DESCRIPTORES: Anciano. Conducta. Vivienda. 


\section{INTRODUCTION}

There is a worldwide tendency for the elderly to live alone, especially women who are older, widowed and poor. ${ }^{1}$ In Brazil, among people aged 60 or older, $13.8 \%$ live in one-person households - those composed of a single person. There is evidence of a positive correlation between the proportion of elderly individuals and the proportion of one-person household units. ${ }^{2}$

National studies on this subject are scarce. A study researched the diverse conditional aspects of the lives of elderly individuals who live alone. It called attention to the fact that spirituality and social activity were strategies employed by them to handle loneliness. The elderly individuals received help in everyday practical situations, especially from their family members and, in lower numbers, from friends and neighbors. There was no mention of help offered by organs of the state. ${ }^{3}$

In the international scenario, many studies have been conducted regarding this theme and they claim that living alone, for elderly individuals, can be a risk factor for morbidity, mortality and lower quality of life, generating high demand for healthcare services. ${ }^{4-5}$ This happens due to the aging process, whose set of changes results in increased dependency in terms of needing help when conducting activities of daily living; thus, living alone can be considered a complex circumstance.

Facing the complex factors involved in this situation, it is necessary to know which strategies were developed by elderly individuals to live alone, be it an option or a life circumstance. We consider strategies "[...] the behaviors, manifested or not, aiming at minimizing the action of environmental conditions that cause harm and losses to the individual and, at the same time, increase their chances of recovery and well-being" 6:1351 The developed strategies become behaviors, ${ }^{6}$ which are understood as an individual's set of reactions to stimuli that are objectively observable. The adoption of a behavior involves many factors that are individual and collective, which vary from person to person; and the maintenance of these behaviors is linked to the prospect of success. ${ }^{7}$

In view of the evident increase in the number of elderly individuals who live alone in Brazil and this being a situation that needs to be investigated nationally, we ask: what are the strategies developed by elderly individuals so they can live alone facing physical, economical, emotional and health problems that possibly arise from the aging process? To answer this question, the aim of this study was to analyze strategies developed by the elderly in order to live alone.

\section{METHODS}

An exploratory study, with a qualitative approach, ${ }^{8}$ was conducted with participants selected from the cohort study Porto Alegre Longitudinal Aging (PALA) ${ }^{9}$ and from the records of the Basic Health Unit (BHU) of a teaching hospital in the state of Rio Grande do Sul, which is a reference unit for the neighborhoods where the elderly from the PALA live. This service, as well as the researched area, belong to the city's sanitary district with the highest proportion of elderly individuals. ${ }^{10}$

The researchers decided to select participants from the cohort and users of the BHU for the investigation on the recommendation of a study ${ }^{3}$ already conducted in the Brazilian scenario with elderly individuals who live alone. This study calls attention to the difficulty of access to this population because of their fear of sharing information and the feeling of vulnerability they report. Therefore, we intended to have easier access to the participants, since they were already linked to a study/reference service they trusted.

The participants were selected by intentional sampling. ${ }^{8}$ Elderly individuals from different age groups participated, with the aim of contemplating younger and older elderly individuals from both genders. The inclusion criteria were: being a subject from the PALA cohort and/or living in the area assisted by the aforementioned $\mathrm{BHU}$; being registered in the unit and who self-reported as living alone for more than six months. Exclusion criteria were: failing to be located after three attempts at different times and days of the week, including Saturdays and Sundays, by telephone or in home visits.

From the PALA cohort, we identified eight elderly individuals who lived alone, of which four met the inclusion criteria. For gathering at the BHU, we located 10 elderly individuals who met the inclusion criteria after recommendations from the healthcare professionals. The sample included a sufficient number of elderly individuals for the theoretical saturation of information, ${ }^{8}$ totaling 14 participants.

Information were collected between April and September 2012, through structured inter- 
views with open-ended and close-ended questions. From the 14 interviews, five were conducted in the presence of a companion, observing the elderly individuals' preferences.

We used thematic analysis, ${ }^{11}$ with support from the software Qualitative Solutions Research NVivo (QSR NVivo) 8.0. This content analysis technique is carried out in three stages: 1) pre-analysis, 2) exploration of the subject and 3) treatment and interpretation of results. ${ }^{11}$ The data regarding the participants' characteristics were analyzed by means of descriptive statistics.

The research proposal was approved by the Research Ethics Committee of the institution under protocol number 120058/2012 and met the terms of resolution number 196/1996. ${ }^{12}$ We obtained authorization from the coordinators of the PALA study for use of information. Participants signed a free and informed consent form, with a written version for the elderly individuals from the PALA and another for the individuals from the BHU. The participants were identified by codes to have their anonymity preserved.

\section{RESULTS AND DISCUSSION}

Of the 14 elderly interviewees, 11 were female. The interviewees' ages varied between 60 and 91 years, with a mean of 79.3 (standard deviation $[S D] \pm 9.2)$. The mean length of education was 8.6 years $(\mathrm{SD} \pm 4.8)$. Most of them were widowed and lived with up to two minimum wages. The mean time they had been living alone was 19 years $(\mathrm{SD} \pm 14.2)$, varying between three and 60 years. As for the reasons for living alone, most (12) interviewees said it was because of the death of those who lived with them.

Analysis of the produced material allowed to group the interviewees' speeches under two empirical categories, according to the themes that emerged, as presented in Table 1.

Table 1 - Description of strategies developed by the elderly to live alone according to the identified behaviors. Porto Alegre, Rio Grande do Sul, Brazil, 2013

\begin{tabular}{|l|l|l|}
\hline Strategies & Behaviors & Findings \\
\hline Strategy $\mathbf{1}$ & Behaviors in search of social support & $\begin{array}{l}\text { Look for support from family members, friends and neighbors. } \\
\text { Be a source of support for the family. } \\
\text { Live close to those who provide support. } \\
\text { Keep close affective relationships. }\end{array}$ \\
\hline Strategy $\mathbf{2}$ & Behaviors in search of remaining active & $\begin{array}{l}\text { Practice leisure activities. } \\
\text { Participate in activities of the community. }\end{array}$ \\
\hline Strategy $\mathbf{3}$ & Behaviors in search of religiosity & $\begin{array}{l}\text { Pray for health. } \\
\text { Pray to avoid loneliness. }\end{array}$ \\
\hline
\end{tabular}

\section{Strategy 1 - Behaviors in search of social support}

Analysis of the findings indicates that the elderly interviewees, even when living alone, presented limitations to perform some activities of daily living and, thus, searched for support from family members, friends and neighbors, especially daughters, to fulfill their needs, as observed in the following speech: to organize the house, my daughter comes and does it [...] I have lunch with her [daughter], too. [Does she cook for you?] She does (I13).

Most elderly interviewees did not report needing for help in self-care. However, they frequently reported difficulties with activities in the community, such as shopping and going to the bank: if I need to go out, I call my son-in-law or my daughter. Because walking alone is showboating. Because I know I am 90 and I know I must know what I should do (I10). These difficulties were associated to physical limitations, such as the weight of groceries and fear of falling; or issues of security, such as going to the bank. This confirms the findings of a study in which one of the biggest difficulties for elderly individuals who lived alone was the need for physical security. ${ }^{13}$

Social support is fundamental in order to handle specific issues of old age. Social support is defined as the total resources offered to other people, forming mutual exchanges in which both those who receive and those who offer are benefited. Its function is to provide the emotional and practical support that individuals need. It is considered one of the most important predictors for physical health and well-being, consisting of a process that involves individuals and their social networks with the aim of satisfying their needs, 
providing and complementing resources and handling new situations. ${ }^{14}$

A social support network refers to the organization of relationships among people. A formal support network consists of public policies directed at the elderly population in general, gathering healthcare services. The informal support network has characteristics such as spontaneity and reciprocity, which help the elderly keep relationships and provide well-being. It consists of family, community, friends and neighbors. ${ }^{14}$

In Brazil, as shown in this study, the family usually provides care for the elderly and, in their absence, friends and neighbors do so. There are no formal state programs effectively applied to provide care for the elderly who are not helped by their families and for whom institutionalization is still the main alternative. ${ }^{3}$ Most of the elderly interviewees also referred to institutionalization as the first choice when they cannot live alone anymore, even among those who have children: I will have to surrender myself to a geriatric house or some such thing (I6).

An alarming aspect related to the capacity to perform activities of daily living and self-care was the significant number of reports of falling. Among the interviewees, ten reported at least one fall at home or on the street in the last year: a while ago, I fell near the front door, then I couldn't get up and I couldn't even reach the phone. When I fall, I can't get up. [...] Then, I crawled like a child to the sofa (I1). An investigation shows that elderly individuals who live alone tend to fall more frequently than those who live with other people. ${ }^{4}$

Falls usually happen at home. The consequences of lesions on older people are more serious than those on younger people. In the case of lesions of the same severity, elderly individuals suffer more incapacity, longer hospital stay and rehabilitation, higher dependency later on and even risk of death.

The traditional perception of falls as "accidents" resulted in a historic negligence of this public health area. Most falls can be prevented. Buildings must consider the health and security needs of the elderly, as well as physical obstacles in houses. An assessment by healthcare professionals through home visits is an alternative, where they can suggest or help in adapting the house. ${ }^{1}$

The elderly individuals called attention, with no questioning regarding the subject, to the fact that they commonly were the providers of support for the family, friends, neighbors and, especially, children and grandchildren. The main form of support is financial: now my grandson is unemployed. He had not finished college and I am paying it for him [...] I feel happy about it (I4). The importance that the elderly individuals give to the fact that they are also support providers calls attention. A study showed that the elderly individuals' self-esteem may be shaken by the perception of dependency, lack of autonomy and impossibility to return the help they receive. Therefore, more balanced exchange relationships cause higher physical and psychological benefits for them, ${ }^{14}$ which may be a possible explanation for their satisfaction in helping family members and friends, highlighting said help.

We identified in the elderly individuals' speeches that living close to support providers made it easier to receive it: live close to people, 'cause nobody lives alone. I can live alone, but there should be somebody to the right or to the left to ask for help. Of course! (I12). The elderly individuals who had more than one child lived close to the one who provided the most support. The findings show that proximity to the children's home can be understood as a behavior both from the elderly individuals and from the family in order to support them in their activities of daily living and to be readily available in case of need. The speeches from the I3 interviewee and her daughter (present at the time of the interview) exemplify this finding: I am always observing her [the elderly individual]. In the morning, I put the paper under the door, with a small part sticking out, so that I can observe it. If she gets the paper, it's a sign that she already got up, that she is fine, get it? (I3's daughter).

In addition to geographical proximity, closeness in affective relationships with friends and neighbors was also mentioned as an important aspect in the search for social support, especially among those who did not live close to their children or those who did not have them: I also left my key [from the house] at the bazaar [close to the elderly individual's home]. They are trustworthy people. I told them that, if one day I lose my key, or if I need something, they have it. They are very caring, they are very good to me (I8).

This closeness and/or good relationship with friends and neighbors is essential for maintaining friendship and companionship. Moreover, it also enables the elderly individuals to have someone to ask for help in case they need, or even to help in activities of daily living, including the mainte- 
nance of their security. ${ }^{3}$ Elderly individuals who never married or did not have children develop, throughout the years, an extrafamilial lifestyle, enhancing their relationships with friends and guaranteeing the maintenance of an independent life in old age. ${ }^{15}$

The strategy that includes behaviors of search for social support - especially informal support, provided by family members, friends and neighbors - is also used. Our findings show that, despite their independent lifestyle, the elderly interviewees presented limitations for some activities of daily living. It is essential for them to receive support so they can perform these activities and, at the same time, remain alone and safe at their homes.

\section{Strategy 2 - Behaviors in search of remaining active}

The findings show that despite the limitations that are inherent to old age, the elderly individuals try to keep active: I go out a lot during the day. During the day you cannot find me at home because I have many activities [...] I do gymnastics, exercises, knitting, handicraft pieces, I do a lot of things. I cross stitch. It's very nice, it's a very good thing. It is good entertainment (I5).

These activities received great attention in the speeches of the participants because they represent a way to put body and mind to work, keeping busy and productive. This fact contradicts studies conducted with this population, ${ }^{3,16}$ which do not present in their results aspects related to leisure activities. We infer that higher education and socio-economic levels where the elderly individuals live may have influenced the adoption of such activities.

A study with elderly individuals from the state of São Paulo found that leisure activities, such as watching television and doing handicrafts, can have a protective effect on functional capacity, since they involve learning, cognitive stimulus and compensatory mechanisms from the social support network. ${ }^{17}$

The awareness that certain behaviors bring benefits for the individuals acts as a motivational factor for their maintenance, ${ }^{7}$ something commonly observed in relation to this category, as shown in the following speech: I do extremely hard crosswords. So I have a very good memory. I don't need to write stuff down [...] the elderly sometimes have problems, but that's because they don't do crosswords (I4).
Another identified behavior that seems to have a positive effect on the elderly is participating in community activities. From the 14 interviewees, nine participated in groups linked to the university, to health care services, to social clubs, to volunteer or religious institutions: try to have some activity, participate, because it's useless to live alone and stay boxed in at home with no one to talk with. My group is very fun and the people there are very nice! We have many activities there. For example, next week we will cook carreteiro rice. On the $29^{\text {th }}$, we will throw a June party [...] and we have a protest scheduled for September [...] you can exchange telephone numbers, e-mails and everything with the people you like the most (I14).

Other studies rarely report this population's participation in groups, which disagrees with this investigation. Activity groups have an important role for elderly individuals who live alone, however this kind of initiative is still incipient and does not meet the demand created by those who do not adapt to defined activities. ${ }^{3,16}$ These are important actions, given that feeling socially included is a considerable benefit for this group by decreasing monotony and sadness and by reaffirming the possibility of being active. ${ }^{7}$ Furthermore, relationship with friends resulting from group participation is a protection against functional losses and it also enables relationships of cooperation and interactivity, demonstrating the relevance of social and affective relationships. ${ }^{17}$

Behaviors in search of remaining active through leisure activities and participation in community activities are part of a strategy that enables higher self-esteem for the elderly, avoids idleness, has a protective effect against functional capacity losses, helps the maintenance or the creation of friendship relationships and offers possible sources and/or exchanges of support. Higher availability of activity groups is among the alternatives to increase the use of this strategy, with higher diversity of activities, contemplating the many preferences of elderly individuals and the availability of these groups in isolated communities. This facilitates the movement of people living in these places and, consequently, increases their participation.

\section{Strategy 3 - Behaviors in search of religiosity}

In this study, we opted for the term "religiosity", because all elderly individuals mentioned specific religions, with their practices and rituals. Religion may be understood as an organized 
system of beliefs, practices, rituals and symbols destined to facilitate the individuals proximity to the sacred and transcendent. ${ }^{18}$

Religious practices were highlighted as important aspects for most elderly individuals in this research, considering that religious behaviors are very frequent in old age. ${ }^{19}$ The most frequently mentioned activities were individual practices, such as prayer. Group practices, such as religious rituals, were also mentioned, but not as frequently. A study that investigated religiosity among elderly individuals admitted to a geriatric ward reported that physical limitations, such as locomotion problems, fear of falling and fear of going out unaccompanied, make them prefer individual practices. ${ }^{20}$

Therefore, one of the identified behaviors was prayer for health, as shown in the following speeches: I was hospitalized for 40 days and the doctors said I wouldn't walk anymore, but through my prayer I walked again (I12). I thank God everyday [...] Jesus blesses me so I don't have to buy medicines (I9). For the elderly individuals, remaining independent and autonomous is usually more associated with health than with the lack of illnesses, a fact that is clear in the following speech: I care for myself and every day I ask God to help me stay that way (I3).

Studies show the implications that religiosity may have on phenomena related to health and disease, with an emphasis on its role as a coping strategy when experiencing the health-disease process. ${ }^{19,21-22}$ A study found that religious coping has the function of regulating the emotional response caused by the bodily experience of incapacity, since, in the perception of the elderly individuals in this study, the realities of functional incapacity were difficult and painful. ${ }^{21}$

For some elderly individuals in this study, in addition to repercussions on physical health, the religious practice of praying helps in avoiding the loneliness implied in the situation of living alone: some days I wake up sad, I don't know. Then I argue with myself, I say: 'wake up! Go to work!'. Some days ago my sister visited me, she went to the kitchen and said: 'who are you talking to?' God is listening to me! He does not leave me alone! (I11). For these individuals, "the presence of God" represents company that alleviates loneliness, compensating the need for another human being. ${ }^{21}$

National studies show that, in order to handle loneliness, female elderly individuals who lived alone adopted compensatory mecha- nisms related to religiosity. ${ }^{3,16}$ In the international context, a review of almost 850 studies examined the relationship between religiosity and mental health, reinforcing the association of religious involvement with higher levels of life satisfaction, well-being, hope and optimism. ${ }^{23}$

The strategy that involves behaviors in search of religiosity has positive repercussions on the physical and mental health of elderly individuals, since according to what is highlighted in literature, it offers specific benefits for those who live alone, especially in relation to compensatory mechanisms for avoiding loneliness. However, it is necessary to analyze this practice. A study warns that religious belief is loaded with disbelief in public healthcare services. When the elderly pray to solve their health problems, incapacities or loneliness, they transfer to God the responsibility for coping or solving their situation. Such behavior generates passivity and conformism, which tend to naturalize the process of ageing with incapacities. This is a characteristic of the Brazilian culture that collaborates for minimizing social and governmental responsibility. ${ }^{21}$

\section{CONCLUSIONS}

The analysis of strategies developed by the elderly to live alone helps the broadening of knowledge regarding their routines and the understanding of how they handle the difficulties they face daily and the available resources for that.

A study reaching a more representative sample of the elderly population who live alone can paint a more comprehensive picture of this population, investigating, among other aspects, the assessment of functional capacity and the support networks of these elderly individuals. We suggest the analysis of groups from different socioeconomic levels and cultural contexts, since there may be considerable differences in developed strategies and their characteristics.

There are clear nursing problems regarding elderly individuals who live alone, such as limitations for performing some everyday activities and the high number of falls. The roles of nurses and healthcare teams as important intervention devices in these problems may be based on higher incentives for adopting the behaviors identified in this study and in the adequate assessment of elderly individuals who are capable or not capable of living alone, in addition to meeting their families. 
Therefore, more alternatives for formal support would be developed, qualifying care practices and enabling the planning of health actions focused on these individuals, in a perspective of individual assessment and social support. Such measure would encourage promoting and protective behaviors both for health and for wellbeing, helping elderly individuals in the "task" of living alone.

\section{REFERENCES}

1. Organização Mundial da Saúde. Envelhecimento ativo: uma política de saúde. Brasília (DF): Organização Pan-Americana de Saúde; 2005.

2. Instituto Brasileiro de Geografia e Estatística (IBGE). Censo demográfico 2010: famílias e domicílios. Rio de Janeiro (RJ) [online]. 2010. [acesso 2013 Mai 20]. Disponível em: ftp://ftp.ibge.gov.br/Censos/ Censo_Demografico_2010/Familias_e_Domicilios/ censo_fam_dom.pdf

3. Camargos MCS. Enfim só: um olhar sobre o universo de pessoas idosas que moram sozinhas no município de Belo Horizonte (MG) [tese]. Belo Horizonte (MG): Universidade Federal de Minas Gerais. Centro de Desenvolvimento e Planejamento Regional; 2008.

4. Sok SR, Yun EK. A comparison of physical health status, self-esteem, family support and healthpromoting behaviours between aged living alone and living with family in Korea. J Clin Nurs. 2011 Jun; 20(11-12):1606-12.

5. Kandler U, Meisinger C, Baumert J, Löwel H. Living alone is a risk factor or mortality in men but not women from the general population: a prospective cohort study. BMC Public Health [online]. 2007 [acesso 2013 Jul 31]; 7(335). Disponível em: http://www.ncbi.nlm.nih.gov/pmc/articles/ PMC2225416/pdf/1471-2458-7-335.pdf

6. Tavares JSC, Trad LAB. Estratégias de enfrentamento do câncer de mama: um estudo de caso com famílias de mulheres mastectomizadas. Ciênc Saúde Coletiva. 2010; 15(1):349-58.

7. Silva MCS, Lautert L. O senso de auto-eficácia na manutenção de comportamentos promotores de saúde de idosos. Rev Esc Enferm USP [online]. 2010 [acesso 2013 Mai 20]; 44(1). Disponível em: http:/ / www.scielo.br/scielo.php?script=sci_arttext\&pid= S008062342010000100009\&lng $=$ en\&nrm $=$ iso

8. Polit DF, Beck CT, Hungler BP. Fundamentos de pesquisa em enfermagem: métodos, avaliação e utilização. $5^{\mathrm{a}}$ ed. Porto Alegre (RS): Artmed; 2004.

9. Rinaldi J. Relação da satisfação de vida e aspectos biopsicossociais no estudo Porto Alegre Longitudinal Aging (PALA) [tese]. Porto Alegre (RS): Universidade Federal do Rio Grande do Sul. Faculdade de Medicina; 2010.
10. Instituto Brasileiro de Geografia e Estatística. Síntese dos indicadores sociais: uma análise das condições de vida da população brasileira [online]. Rio de Janeiro (RJ): IBGE; 2010 [acesso 2013 Mai 20]. Disponível em: http://www.ibge.gov.br/ home/estatistica/populacao/condicaodevida/ indicadoresminimos/sinteseindicsociais2010/ SIS_2010.pdf

11. Minayo MCS. O desafio do conhecimento: pesquisa qualitativa em saúde. $8^{\text {a }}$ ed. São Paulo (SP): Hucitec; 2004.

12. Ministério da Saúde (BR). Conselho Nacional de Saúde, Comissão Nacional de Ética em Pesquisa. Resolução No 196 de 10 de outubro de 1996: diretrizes e normas regulamentadoras de pesquisa envolvendo seres humanos. Brasília (DF): MS; 1996.

13. Ramos JL, Ramos C, Menezes MR, Meira EC. Idosos que moram sozinhos: desafios e potencialidades do cotidiano. Rev Baiana Enferm. 2010 Dez-Jan; 24(1-3):43-54.

14. Rosa TEC. Redes de apoio social. In: Litvoc J, Brito FC, organizadores. Envelhecimento: prevenção e promoção da saúde. São Paulo (SP): Atheneu; 2004. p. 203-17.

15. Larsson K, Silverstein M. The effects of marital and parental status on informal support and service utilization: a study of older swedes living alone. J Aging Stud. 2004 Mai; 18(2):231-44.

16. Capitanini MES. Sentimentos de solidão, bem-estar subjetivo e relaç̃oes sociais em idosas vivendo sós [dissertação]. Campinas (SP): Universidade Estadual de Campinas. Faculdade de Educação; 2000.

17. Orsi E, Xavier AJ, Ramos LR. Trabalho, suporte social e lazer protegem idosos da perda funcional: estudo epidoso. Rev Saúde Pública. 2011; 45(4):68592.

18. Koenig HG, Mccullough ME, Larson DB. Handbook of religion and health. New York (US): Oxford University; 2001.

19. Teixeira JJV, Lefèvre F. Significado da intervenção médica e da fé religiosa para o paciente idoso com câncer. Ciênc Saúde Coletiva. 2008 Jul-Ago; 13(4):1247-56.

20. Duarte FM, Wanderley KS. Religião e espiritualidade de idosos internados em uma enfermaria geriátrica. Psicol Teor Pesqui. 2011 Jan-Mar; 27(1):49-53.

21. Santos WJ, Giacomin KC, Pereira JK, Firmo JOA. Enfrentamento da incapacidade funcional por idosos por meio de crenças religiosas. Ciênc Saúde Coletiva [online]; 2013 [acesso 2014 Ago 06]; 18(8):2319-28. Disponível em: http://www.scielo. $\mathrm{br} / \mathrm{pdf} / \mathrm{csc} / \mathrm{v} 18 \mathrm{n} 8 / 16 . \mathrm{pdf}$

22. Chaves ECL, Paulino CFP, Souza VHS, Mesquita AC, Carvalho FSC, Nogueira DA. Qualidade de vida, sintomas depressivos e religiosidade em idosos: um estudo transversal. Texto Contexto 
Enferm [online]; 2014 Jul-Set [acesso 2015 Fev 08]; 23(3):648-55. Disponível em: http:/ / www.scielo.br/ pdf/tce/v23n3/pt_0104-0707-tce-23-03-00648.pdf
23. Koenig HG, Larson DB, Larson SS. Religion and coping with serious medical illness. Ann Pharmacother. 2001 Mar; 35(3):352-9. 